This document was prepared in conjunction with work accomplished under Contract No. DE-AC09-96SR18500 with the U.S. Department of Energy.

This work was prepared under an agreement with and funded by the U.S. Government. Neither the U. S. Government or its employees, nor any of its contractors, subcontractors or their employees, makes any express or implied: 1 . warranty or assumes any legal liability for the accuracy, completeness, or for the use or results of such use of any information, product, or process disclosed; or 2 . representation that such use or results of such use would not infringe privately owned rights; or 3 . endorsement or recommendation of any specifically identified commercial product, process, or service. Any views and opinions of authors expressed in this work do not necessarily state or reflect those of the United States Government, or its contractors, or subcontractors. 


\title{
EFFECTS OF TRITIUM GAS EXPOSURE ON THE DYNAMIC MECHANICAL PROPERTIES OF EPDM ELASTOMER
}

\author{
Elliot A. Clark, Gregory C. Staack
}

Savannah River National Laboratory, Building 773-A, Aiken, SC 29808; elliot.clark@srnl.doe.gov

\begin{abstract}
Samples of ethylene propylene diene monomer (EPDM) elastomer were exposed to tritium gas in closed containers initially at $101 \mathrm{kPa}$ (1 atmosphere) pressure and ambient temperature for about one week. Tritium exposure effects on the samples were characterized by dynamic mechanical analysis (DMA) and radiolysis products were characterized by measuring the total final pressure and composition in the exposure containers at the end of exposure period. There was no effect of one week tritium exposure on the glass transition temperature, Tg, of the samples tested. Impurity gases produced in the closed containers included HT and lesser amounts of $\mathrm{H}_{2}, \mathrm{DTO}$, and $\mathrm{CT}_{4}$. The total pressure remained the same during exposure.
\end{abstract}

\section{INTRODUCTION}

Despite the well-known degradation of polymers when exposed to ionizing radiation ${ }^{1}$, there are applications in which polymers are exposed to ionizing radiation for which they are uniquely suited and so are employed despite their limited service life. Besides ubiquitous applications such as electrical power and signal cable insulation applications in very low tritium concentration environments, various polymers are used as seals for both static and dynamic ("make-andbreak") uses. Examples include valve stem tips, valve packing, and other various O-ring and other seals. Commercially available gas-handling equipment often employs polymers and it can be prohibitively expensive to find non-polymeric alternatives.

A program has been underway at the Savannah River National Laboratory for several years to improve the understanding of the effects of tritium exposure on polymers. This program studied tritium effects on the three thermoplastics ultra-high molecular weight polyethylene (UHMW-PE), polytetrafluoroethylene

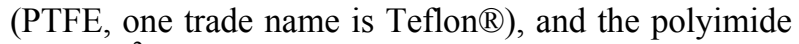
Vespel $\AA^{\circledR}$. Ethylene propylene diene monomer (EPDM) rubber is a commonly used elastomer that is relatively resistant to radiation and has been employed in tritium processing facilities. This paper reports initial results in characterizing effects of tritium gas exposure on several types of EPDM.

\section{SAMPLE EXPOSURE TO TRITIUM GAS}

Sheets of Nordel ${ }^{\mathrm{TM}} 1440$ and Royalene $(580 \mathrm{H}$ were obtained from Los Alamos National Laboratory (LANL). Both standard graphite filled sheets and formulations synthesized without graphite at LANL were provided. The filled Nordel ${ }^{\mathrm{TM}} 1440$ had a nominal thickness of $1.94 \mathrm{~mm}$, the filled Royalene ${ }^{\circledR} 5800.85$ $\mathrm{mm}$, the unfilled Nordel $^{\mathrm{TM}} 0.7 \mathrm{~mm}$ and the unfilled Royalene ${ }^{\circledR} 0.65 \mathrm{~mm}$. The filled polymers appeared black, and the unfilled versions appeared light grey. Rectangular slab-shaped samples having nominal lengths of $33 \mathrm{~mm}$ and nominal width of $9 \mathrm{~mm}$ were cut from the sheets.

Exposure containers were designed per ASME B31.3 and per Savannah River Site (SRS) Tritium Facility requirements. The design limits are maximum temperature of $260^{\circ}$ C. $\left(500^{\circ}\right.$ F. $)$ and maximum pressure of $3447 \mathrm{kPa}$ (500 psig). The containers are tubes having $19.05 \mathrm{~mm}(3 / 4$ ") diameter by $1.244 \mathrm{~mm}$ (0.049") wall thickness, about $203 \mathrm{~mm}$ (8”) long, connected to an adapter and then to a series of two bellows valves (Swagelok H-series). All wetted materials of the containers are Type 316 or Type $316 \mathrm{~L}$ stainless steel.

Spacers were cut from $0.125 \mathrm{~mm}$ thick Type 316 stainless steel sheet. They were cut to be the same width as the samples $(9 \mathrm{~mm})$ and were $50 \mathrm{~mm}$ long. The two ends were bent around each sample to prevent the EPDM samples from contacting one other. Except for incidental contact with the spacers, the samples were not pressed or loaded during exposure.

Each exposure consisted of placing six samples in their spacers placed in one exposure container. The containers were then attached to an experimental tritium handling manifold at the Savannah River Site. The containers were evacuated overnight, and then $99.1 \%$ tritium gas was admitted to $101 \mathrm{kPa}$ (1 atmosphere) nominal pressure. The samples were exposed to tritium for about one week. The exposure temperature in all cases was the ambient temperature in the manifold glovebox. After exposure, samples were tested using Dynamic Mechanical Analysis (DMA). 
Dynamic mechanical analysis consists of applying a known force at one or more frequencies to the sample under study and measuring the displacement of the sample at the location of the force. The DMA calculates the elastic and viscoelastic parameters from the force, displacement, and the geometrical properties of the sample (width, thickness, gage length) and sample holder ("clamp"). The properties measured for this study were the storage modulus (instantaneous elastic constant), the loss modulus (measure of time-dependent visco-elastic deformation), and the quantity tan delta, which is defined as the ratio of the loss modulus to the storage modulus. The phase angle delta is the phase angle between the applied force and the observed displacement.

A TA Instruments Model 2980 DMA was altered to separate the mechanical and electronic parts of the analyzer to allow the DMA to be located in a tritium hood, enabling analysis of the polymer samples. The single cantelever "clamp", or sample holder, was used for this study. Preliminary experiments on unexposed samples were performed to allow DMA parameters such as oscillation amplitude, static force, and autoamplitude to be determined for each polymer. DMA characterization began at $-70^{\circ} \mathrm{C}$., and the temperature increased at $1^{\circ} \mathrm{C}$./minute until $0^{\circ} \mathrm{C}$. The vibration amplitude was chosen to be $40 \mu \mathrm{m}$.

\section{RESULTS and DISCUSSION}

\section{III.A. Gas Analysis after Exposure}

Mass spectroscopy of the gas before and after typical exposure revealed production of $0.24 \mathrm{~mol} \% \mathrm{H}_{2}$ $\left({ }^{1} \mathrm{H}_{2}\right), 7.75 \%$ HT $\left({ }^{1} \mathrm{H}^{3} \mathrm{H}\right), 0.35 \%$ DTO $\left({ }^{2} \mathrm{H}^{3} \mathrm{HO}\right)$, and $0.437 \% \mathrm{CT}_{4}\left(\mathrm{C}^{3} \mathrm{H}_{4}\right)$. The tritium content was $99.1 \%$ before and $90.28 \%$ after this exposure. The total pressure of the container remained the same, within experimental error.

\section{III.B. Dynamic Mechanical Analysis}

The dynamic mechanical properties of EPDM change drastically with temperature through the glass transition (Fig. 1), as expected for this elastomer. Below the glass transition, the storage and loss moduli and tan delta were relatively constant at the various applied load frequencies tested (Figs. 2, 3, 4). Starting at and above the glass transition the storage and loss moduli and $\tan$ delta increased with increasing frequency (Figs. 2, 3, 4).

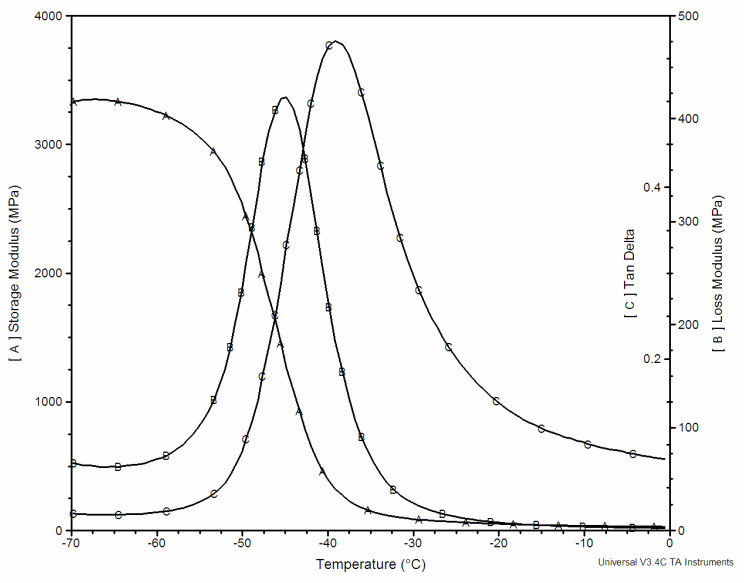

Fig. 1. Storage modulus, loss modulus, and tan delta at $1 \mathrm{~Hz}$ of one-week-exposed filled Nordel ${ }^{\circledR} 1440$ as a function of temperature. Temperature increased $1{ }^{\circ} \mathrm{C} /$ minute during test.

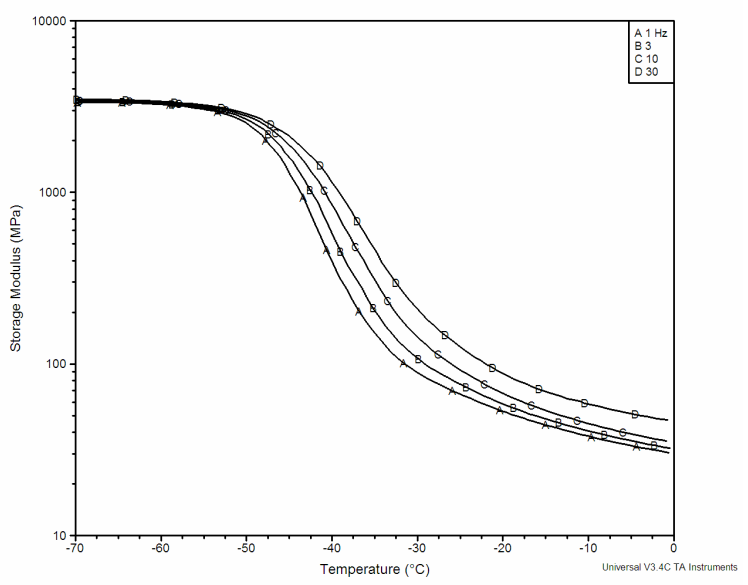

Fig. 2. Logarithm of storage modulus of one-weekexposed filled Nordel ${ }^{\circledR} 1440$ as a function of temperature. Applied frequencies 1, 3, 10, $30 \mathrm{~Hz}$ as noted. 


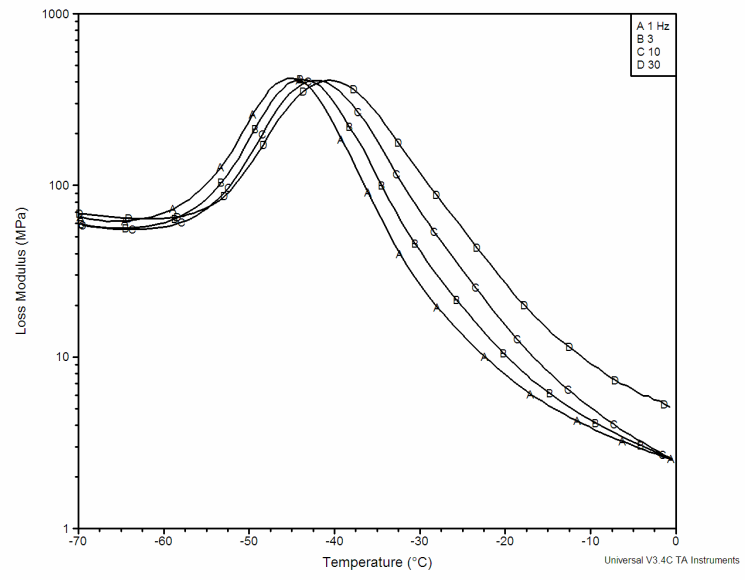

Fig. 3. Logarithm of loss modulus of one-week-exposed filled Nordel ${ }^{\circledR} 1440$ as a function of temperature. Applied frequencies 1, 3, 10,30 Hz as noted.

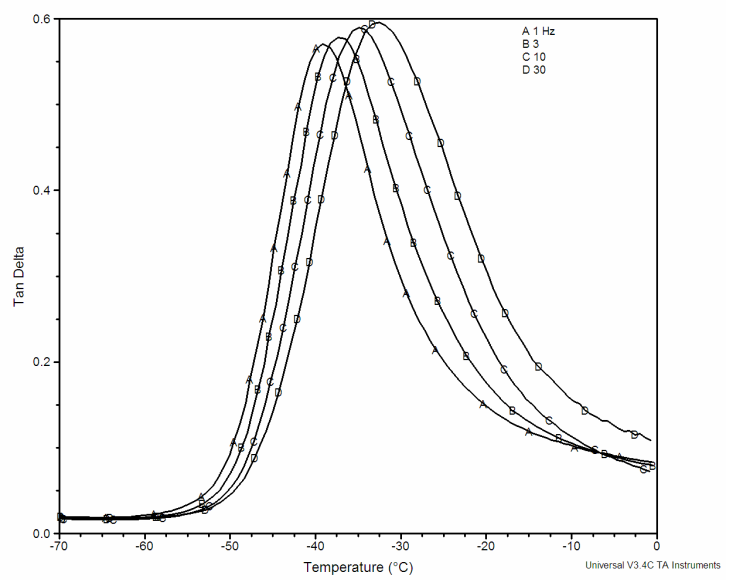

Fig. 4. Tan delta of one-week-exposed Nordel ${ }^{\circledR} 1440$ as a function of temperature. Applied frequencies 1, 3, $10,30 \mathrm{~Hz}$ as noted.

The glass transition temperature $\mathrm{Tg}$ can be determined by several methods, including differential scanning calorimetry (DSC), dilatometry, and DMA. There are at least two accepted methods for determining Tg from DMA data. ASTM E 1640 "Standard Test Method for Assignment of the Glass Transition Temperature by Dynamic Mechanical Analysis" uses the intersection of two tangents of the storage modulus versus temperature curve: the tangent of data below $\mathrm{Tg}$ and the tangent at the inflection point of the sigmoidally changing modulus in the middle of the glass transition. The temperature of the tangents intersection is regarded as being Tg. The standard requires an applied frequency of $1 \mathrm{~Hz}$ and a temperature increase rate of $1^{\circ} \mathrm{C}$ /minute, which were used in these tests. (DMA data at 3,10, and
$30 \mathrm{~Hz}$ were not used to measure Tg.) Either the linear or logarithmic plots can be used for this construction. In this work the linear plot was used. The other accepted method for determining $\mathrm{Tg}$ by DMA is the peak temperature of the loss modulus ${ }^{3}$. Both methods are illustrated in Fig. 5.

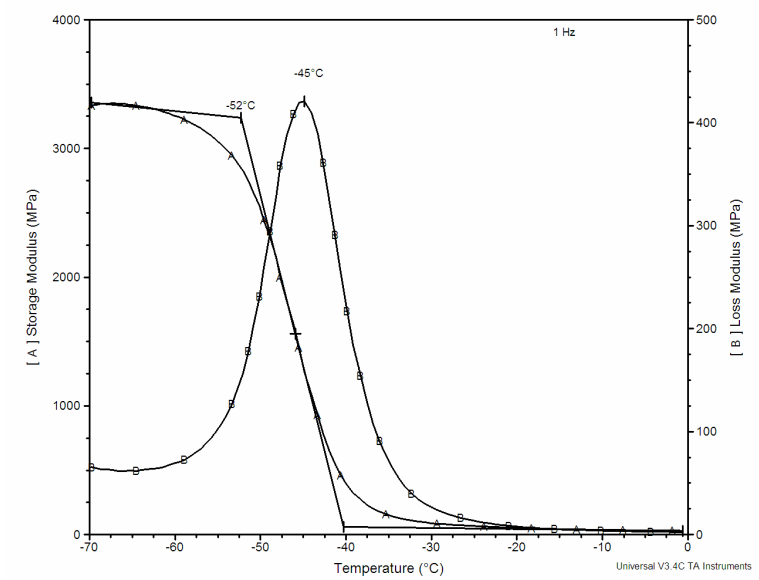

Fig. 5. Storage modulus and loss modulus at $1 \mathrm{~Hz}$ of one-week-exposed filled Nordel ${ }^{\circledR} 1440$ as a function of temperature. Tg measured by both the ASTM E 1640 tangent intersection method and the peak of the loss modulus is illustrated.

There was no effect of the one week tritium exposure on the glass transition of any of the materials studied (Table I.). Likewise, the glass transition temperature did not change with the presence or absence of filler, and it did not depend on the base resin (Nordel $^{\mathrm{TM}} 1440$ versus Royalene ${ }^{\circledR} 580 \mathrm{H}$ in Table I.). The difference in glass transition temperature comparing the two methods of analyzing DMA data was about $6^{\circ} \mathrm{C}$. 


\begin{tabular}{|c|c|c|c|}
\hline \multirow[b]{2}{*}{ Sample } & \multirow[b]{2}{*}{$\frac{\text { Tritium }}{\text { Exposure }}$} & \multicolumn{2}{|c|}{$\operatorname{Tg}\left({ }^{\circ} \mathrm{C}.\right)$} \\
\hline & & $\frac{\text { ASTM E }}{\underline{1640}}$ & $\frac{\begin{array}{c}\text { Loss } \\
\text { Modulus }\end{array}}{\underline{\text { Peak }}}$ \\
\hline $\begin{array}{l}\text { Nordel } \\
\text { Filled }\end{array}$ & none & -52 & -44 \\
\hline " & 1 Week & -49 & -44 \\
\hline " & 1 Week & -54 & -44 \\
\hline “ & 1 Week & -52 & -45 \\
\hline $\begin{array}{l}\text { Royalene } \\
\text { filled }\end{array}$ & none & -56 & -49 \\
\hline " & 1 Week & -55 & -49 \\
\hline “ & 1 Week & -55 & -50 \\
\hline " & 1 Week & -54 & -49 \\
\hline $\begin{array}{l}\text { Nordel } \\
\text { Unfilled }\end{array}$ & none & -52 & -46 \\
\hline “" & 1 Week & -53 & -46 \\
\hline “ & 1 Week & -53 & -46 \\
\hline “ & 1 Week & -52 & -46 \\
\hline $\begin{array}{l}\text { Royalene } \\
\text { Unfilled }\end{array}$ & none & -55 & -49 \\
\hline " & 1 Week & -55 & -49 \\
\hline "“ & 1 Week & -55 & -49 \\
\hline “ & 1 Week & -54 & -50 \\
\hline
\end{tabular}

\section{SUMMARY}

Samples of Nordel ${ }^{\mathrm{TM}} 1440$ and Royalene ${ }^{\circledR} 580 \mathrm{H}$ EPDM, both unfilled and graphite filled, were exposed to $101 \mathrm{kPa}$ tritium gas at ambient temperature for about one week. Impurity gases produced in the closed container include HT and lesser amounts of $\mathrm{H}_{2}$, DTO, and $\mathrm{CT}_{4}$. The total pressure remained constant. Dynamic mechanical analysis revealed no change of glass transition temperature with tritium exposure, and no variation of glass transition temperature with polymer grade or presence of filler.

\section{ACKNOWLEDGMENTS}

The assistance of Wanda Britt (sample characterization before testing, sample tracking and handling, DMA operation), Mike Thomas (DMA installation, facility interface), Kip Neikirk (design and fabrication of exposure containers), and Dante Pilgrim (sample exposure gas handling) is gratefully acknowledged. Dr. Michael Smith of Los Alamos
National Laboratory provided the samples. This document was prepared in connection with work done under Contract No. DE-AC09-96SR18500 with the U.S. Department of Energy.

\section{REFERENCES}

1. D.C. PHILLIPS, "Effects of Radiation on Polymers", Materials Science and Technology, 4, pp. 85-91 (January 1988).

2. E.A. CLARK, K.L. SHANAHAN, "Effects of Tritium on UHMW-PE, PTFE, AND Vespel ${ }^{\circledR}$ polyimide", Fusion Science and Technology, 52, (November 2007) (in press).

3. L.E. NIELSEN, R.F. LANDEL, Mechanical Properties of Polymers and Composites, 2nd Ed., p. 141, Marcel Dekker, Inc, New York (1994). 